\title{
ORCHID (ORCHIDACEAE) DIVERSITY WITHIN HERBARIUM CROATICUM (ZA) COLLECTION SENSU STRICTO
}

\section{Vedran Šgota $^{1 *}$, Tihana Vilović $^{2}$ \& Ivana Zovko}

${ }^{1}$ Department of Botany, Faculty of Science, University of Zagreb, Marulićev trg 20/II, 10000 Zagreb, Croatia

${ }^{2}$ Department of Pharmaceutical Botany, Faculty of Pharmacy and Biochemistry, University of Zagreb, Schrottova 39, 10000 Zagreb, Croatia

3Šelište bb, 72230 Žepče, Bosna i Hercegovina

Šegota, V. Vilović, T. \& Zovko, I.: Orchid (Orchidaceae) diversity within Herbarium Croaticum (ZA) collection sensu stricto. Nat. Croat., Vol. 28, No. 2, 325-343, 2019, Zagreb.

The collection of orchids within Herbarium Croaticum sensu stricto keeps as many as 1373 herbarium sheets, belonging to 91 taxa (25 genera, 76 species, 11 subspecies and four hybrids). The majority of the collection originates from Croatia while the rest are from neighbouring countries (Slovenia, Serbia, Bosnia \& Herzegovina, Italy, North Macedonia and Montenegro). The most numerous genera are Orchis, Ophrys and Anacamptis, while the most numerous taxa are Gymnadenia conopsea, Platanthera bifolia, Anacamptis morio, Neotinea tridentata, Cephalanthera longifolia and Dactylorhiza maculata. The oldest herbarium sheets date back to 1883 and the average age of the collection is 113 years. The main collectors are Ljudevit Rossi, Dragutin Hirc and Ambroz Haračić. The collection keeps holotypes and isotypes of Epipactis rivularis and Ophrys dinarica, while exsiccates of Malaxis monophyllos, Herminium monorchis and Ophrys $\times$ muellneri are the only evidence of their existence in Croatia. All sheets were digitized and are publically available via virtual herbarium.

Key Words: Croatia, digitization, herbarium, orchids

Šegota, V. Vilović, T. \& Zovko, I.: Raznolikost orhideja (Orchidaceae) u zbirci Hrvatskog Herbarija sensu stricto (ZA). Nat. Croat., Vol. 28, No. 2., 325-343, 2019, Zagreb.

Zbirka orhideja u Hrvatskom herbariju sensu stricto sadrži ukupno 1373 herbarijskih listova, koji pripadaju 91 svojti ( 25 rodova, 76 vrsta, 11 podvrsta i četiri hibrida). Većina zbirke potječe iz Hrvatske i nekoliko susjednih zemalja (Slovenija, Srbija, Bosna i Herzegovina, Italija, Sjeverna Makedonija i Crna Gora). Najbrojniji rodovi su Orchis, Ophrys i Anacamptis, a vrste Gymnadenia conopsea, Platanthera bifolia, Anacamptis morio, Neotinea tridentata, Cephalanthera longifolia i Dactylorhiza maculata. Najstariji primjerci potječu iz 1883., a prosječna starost zbirke je čak 113 godina. Glavni sakupljači su Ljudevit Rossi, Dragutin Hirc i Ambroz Haračić. U zbirci se čuvaju holotipovi i izotipovi vrsta Epipactis rivularis i Ophrys dinarica, a eksikati Malaxis monophyllos, Herminium monorchis i Ophrys $\times$ muellneri su jedini dokaz postojanja ovih vrsta u Hrvatskoj. Svi herbarijski primjerci su digitalizirani i javno su dostupni preko virtualnog herbarija.

Ključne riječi: Hrvatska, digitalizacija, herbarij, orhideje

\section{INTRODUCTION}

The orchid family seems to represent the most fascinating plant family for professional and amateur botanists worldwide. The first interest for orchids in Croatia can be traced back to the beginning of the $20^{\text {th }}$ century, when orchids of island Lošinj (Fleischmann, 1904) and Dalmatia (HAYek, 1913) were studied. In the following period, the focus of orchidological fieldwork in Croatia mostly remained on the Adriatic coast (Hellmayr, 1939-1941; Löschl, 1971; Vöтн 
\& Löschl, 1978; Göltz \& Reinhard, 1986). During the last 20 years, several noteworthy contributions to the Croatian orchid flora were published (PERKo, 1998; Šegota \& Alegro, 2011; Š Egota et al., 2012; Vuković et al., 2013; Zadravec et al., 2013; Jeričević et al., 2015; Zadravec et al., 2015; BoroveČKi-Voska, 2016). Moreover, several important field inventories of particular areas were performed throughout Croatia, e.g. Žumberak Mt. (VRbeK \& Fiedler, 1998), Medvednica Mt. (HrŠAK et al., 1999; ZADRAVEC et al., 2014), island of Vis (KRANJČEv, 2001; BrogGi \& Burri, 2006), Istria and Quarnerro Islands (Kerschbaumsteiner et al., 2002; Hertel \& Hertel, 2003; Griebel, 2009; Vuković et al., 2011), Požega Valley (Zima et al., 2006) and Krka National park (Vuкоvić et al., 2017). Additionally, several popular orchid guidebooks have been published recently (Crvenka, 1999; Pavlus, 2004; KranjČEv, 2005; BoroveČKI-Voska, 2010). According to Flora Croatica Database, there are 183 taxa within 27 genera of orchids in Croatia, 19 of which are endemic (Nikolić, 2019).

The Division of Botany of the Faculty of Science in Zagreb holds two officially registered herbarium collection - Herbarium Croaticum (ZA) and Herbarij Ive $i$ Marije Horvat (ZAHO) (Thiers, 2019). The ZA collection was founded in 1880 and includes herbarium sheets collected by various researchers during the past 200 years. With over 200.000 herbarium sheets it is the oldest and the largest herbarium collection in Croatia. It holds three separate units, namely Herbarium Generale (historical collection formed via exchange with other world herbaria), Herbarium Croaticum sensu stricto (collection of flora of Croatia and, partially, of adjacent countries) and Herbarium Cryptogamicum (collection of algae, mushrooms, lichens and bryophytes).

Besides for the taxonomy and systematics as their primary purpose, herbarium collections can be also used for the analysis of wide range of environmental topics, depending on types of data that can be obtained from specimens. Containing the information on meta-data (date and location), phenotype, phenology, molecular data and biotic interactions of collected herbarium specimens, in recent years few new approaches emerged, such as studies on invasions, habitat change, climate change and pollution (LANG et al., 2019). For example, using herbarium data, a phenological response to climate change in terrestrial orchids has been proven in Hungary, demonstrating that the majority of orchids have shifted their yearly mean flowering to earlier dates during the past 50 years (Molnár et al., 2012a).

Today's information technologies are greatly accelerating scientific research, by providing easy and flexible ways of accessing data collected from all around the world, including herbarium collections (KisLov et al., 2017). At present, the formation of Internet resources of herbarium collections is an important branch of herbarium management, and digitization of collections is a recent trend in many herbaria (FlanNERY, 2012). Public access to such information via herbarium-based databases (virtual herbaria) makes collections more broadly useful and improves scientific research (Smith \& Blagoderov, 2012; Penn et al., 2017). Bearing in mind that more than a half of herbarium collections from some regions of the world may be incorrectly identified (Goodwin et al., 2015), digital collections permit remote access by specialists and more precise identifications. 
World leaders in herbarium digitization are Museum of Natural History in Paris (P) with 5.3 million digitized specimens, Naturalist in Leiden, Netherlands (L) with 4 million digitized specimens, Institute of Botany, New York Botanical Garden (NY) with 2 million digitized specimens and China Academy of Sciences (PE) with 1.8 million digitized specimens (SEREgIN, 2016). Moreover, NY is currently adding 20.000 scans per month, while Smithsonian Institution in Washington (US) is adding 4.000 scans per day, and Royal Botanic Gardens in Kew (K) and The Natural History Museum in London (BM) are adding 3.000 scans per day (SEREGIN, 2016). However, at present, over one million of specimens is kept in at least 61 herbaria (SEREGIN, 2016), thus the majority of world herbaria remains inaccessible via Internet.

In last two decades, several studies based on Croatian herbarium collections have been published (VIDOvić, 2001; HršAK, 2002; ŽEvrnJa \& VlaAdović, 2008; Strgulc Krajšek et al., 2009; ŠEgota et al., 2017; Britvec et al., 2018). As for orchids, recent analyses of herbarium collection were made for all Hungarian (MolNÁr et al., 2012b) and partially Serbian (DJordjević et al., 2017) herbaria.

Digitization of herbarium sheets within ZA collection has initiated in 2015, after the purchase, extensive testing and technical improvements of the equipment (ŠEGota et al., 2017). As many as 28.251 herbarium sheets from ZA and 4.352 herbarium sheets from ZAHO have been digitized so far, out of which 8.322 sheets from ZA and 1.207 from ZAHO have been scanned and are accessible via ZA \& ZAHO Virtual Herbarium (REŠETnIK \& Š Database (Nikolić, 2019).

The aims of this research were to (a) analyse the diversity of the orchid family within Herbarium Croaticum sensu stricto collection, (b) perform revision of some genera and taxa, and c) estimate the average time for digitization and detect the bottlenecks within this process.

\section{MATERIAL AND METHODS}

For the purpose of this survey, we studied in 2016 and 2017 the orchids within Herbarium Croaticum sensu stricto collection (in the following text as ZA), meaning that the specimens from world collection (Herbarium Generale) were not included, in order to study solely the distribution of orchids in Croatia and adjacent countries. Revision of the most of the herbarium material was not done, since majority of orchid taxa are generally difficult to be identified in dry and colourless state. In case of typical subspecies (e.g. Ophrys sphegodes, O. sphegodes subsp. sphegodes, Anacamptis laxiflora, A. laxiflora subsp. laxiflora), we left those taxa separately as noted in collection, since we were unable to clarify which subspecies specimens labelled on species level actually belong to. As for the taxa with problematic geographical distribution (e.g. Neotinea tridentata subsp. commutata and Anacamptis morio subsp. picta), we failed to resolve their identity, thus we left their original nomenclature. In contrast, the specimens named as Nigritella nigra were successfully identified as Gymnadenia rhellicani, based on distinct serrations along the margin of lower bracts (Delforge, 2006). Revision of the genus Himantoglossum was successfully performed. In addition, the whole 
collection is publically available via Flora Croatica Database, as well as ZA \& ZAHO Virtual Herbarium, for further experts' examinations.

The pre-scanning process included cleaning, dusting and translocation of plant material to new format of herbarium sheet adequate for scanning, mounting with pH neutral adhesive tape and gluing of herbarium labels (ŠEGOTA et al., 2017). If the label was covered by a plant or folded, we made it clearly visible, while important broken parts of plant were assembled back to the specimens via adhesive tape or stored within a special envelope. Additionally, a ZA stamp, standard colour palette and scale were provided on each herbarium sheet before the scanning. The metadata of the digital herbarium were stored in Flora Croatica Database (NIKOLIć, 2019), and included all information presented on the herbarium labels; namely, the ID of herbarium sheet, taxon name, geographical reference, habitat data, collector and identifier of each specimen, dates of collection and collection number. Prior to digitizing of the collection, we verified the taxonomy and revealed synonyms.

We used inversed Epson Expression 11000XL Pro A3 scanner to make image files with .tiff extension, named by herbarium sheet's ID. There are no specific regulations regarding image resolution in herbaria worldwide, thus we decided to follow recommendations from SEREGIN (2016), and use a resolution of $300 \mathrm{dpi}$ for regular herbarium sheets and $600 \mathrm{dpi}$ for those of highest importance - exemplary specimens or type specimens. The scanned images in original resolution and extension are kept offline as four backups. Finally, high resolution images were uploaded and published in Flora Croatica Database, as well as in ZA \& ZAHO Virtual Herbarium. Based on the experience gained through orchid digitization, we estimated the average time necessary for digitizing one herbarium sheet.

Taxa names (except type specimens) are cited in text without the author names for simplicity, while the full names are listed in Appendix 1. The nomenclature used in this paper follows phylogenetic approach of BATEMAN et al. (1997) applied in World Checklist of Kew Gardens (WCSP, 2019) and local floras (e.g. DJordjević et al., 2018). However, we left in brackets the names still in use in Flora Croatica Database.

\section{RESULTS AND DISCUSSION}

As many as 1373 herbarium sheets with orchids were restored and digitized, belonging to 25 genera, 91 taxa, including 11 subspecies and four hybrids. Several specimens remained unidentified, namely 24 herbarium sheets of the genus Epipactis, and four sheets of the genus Ophrys. Similarly, the majority of the unidentifiable orchid records from Herbarium Database of Hungarian Orchids belong to the taxonomically critical genus Epipactis (MoLNÁr, 2012b). This is not unusual, since orchids are being identified using, in most cases, colour and shape of various floral structures, generally not recognisable on dried plants. In Croatia, 183 orchid taxa have been recorded so far (NiкоLıć, 2018), thus ZA collection encompasses $50 \%$ of the national diversity of orchids. The full list of orchid taxa from ZA is provided in Appendix 1. Regarding the Red listed taxa (NiкоLı́́ \& TopIć, 2005), all of them are represented within ZA collection, except Orchis spitzelii Saut. ex Koch. Two holotypes have been found, namely, Epipactis rivularis Kranjčev et Čičmir (ZA15691) (Fig. 1) and Ophrys dinarica Kranjčev et P. Delforge (ZA14344) (Fig. 2), as well as isotypes of both taxa (ZA28360, ZA14344) (Fig. 2). 

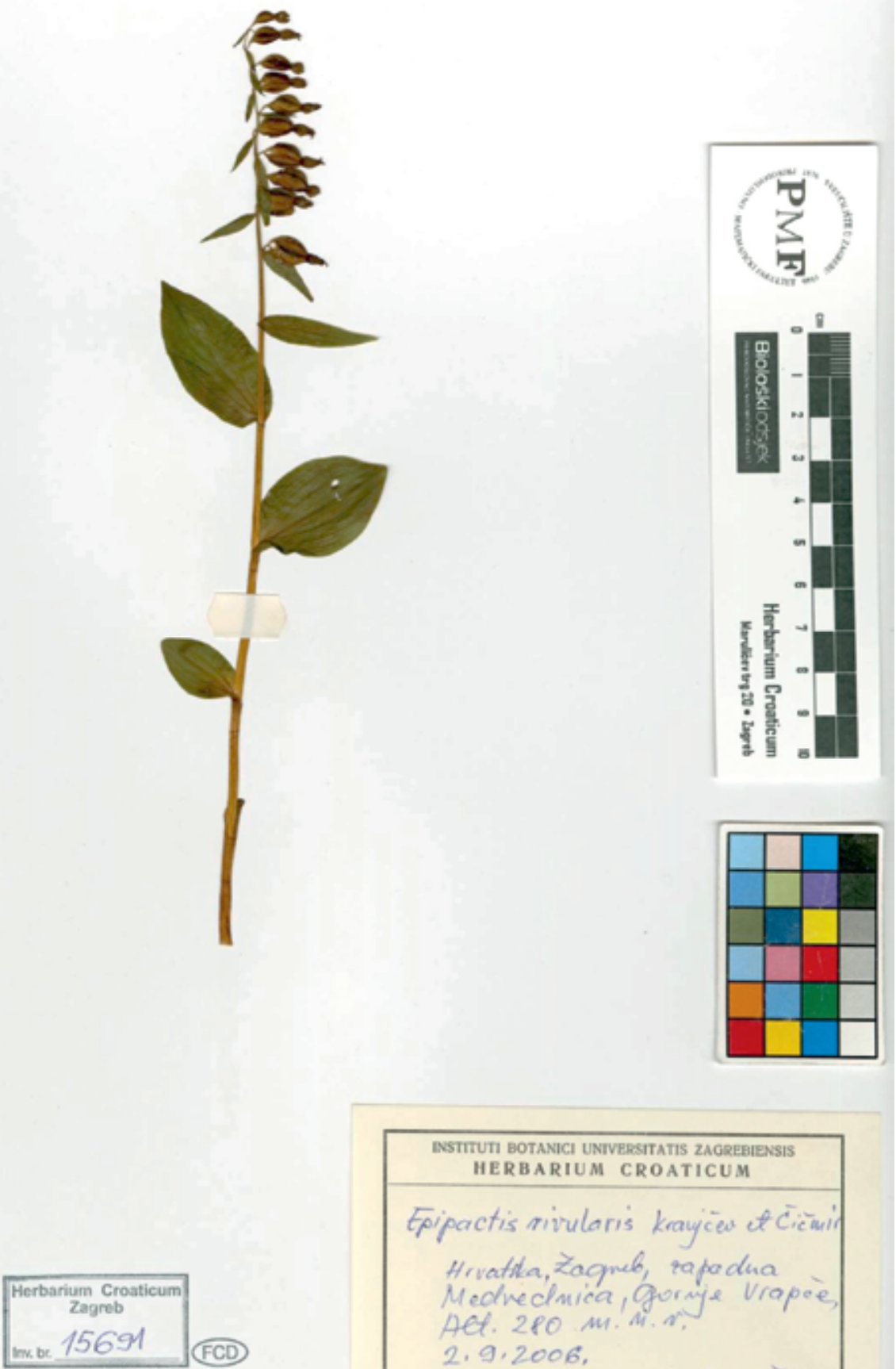

NNTITUTI BOTANICI UNIVERSTTATIS ZAGREBIENSIS HERBARIUM CROATICUM

Epipactis rivularis krayceu et Cicmin Hrvatila, Zagueb, tapadua Medvednica, gormie Vrapee Det. 280 m. Mi.n. 2.9 .2006 , Holorip Leqet det, Roko Ciciui,

Fig. 1. Holotype of Epipactis rivularis Kranjčev et Čičmir (ZA15691) 


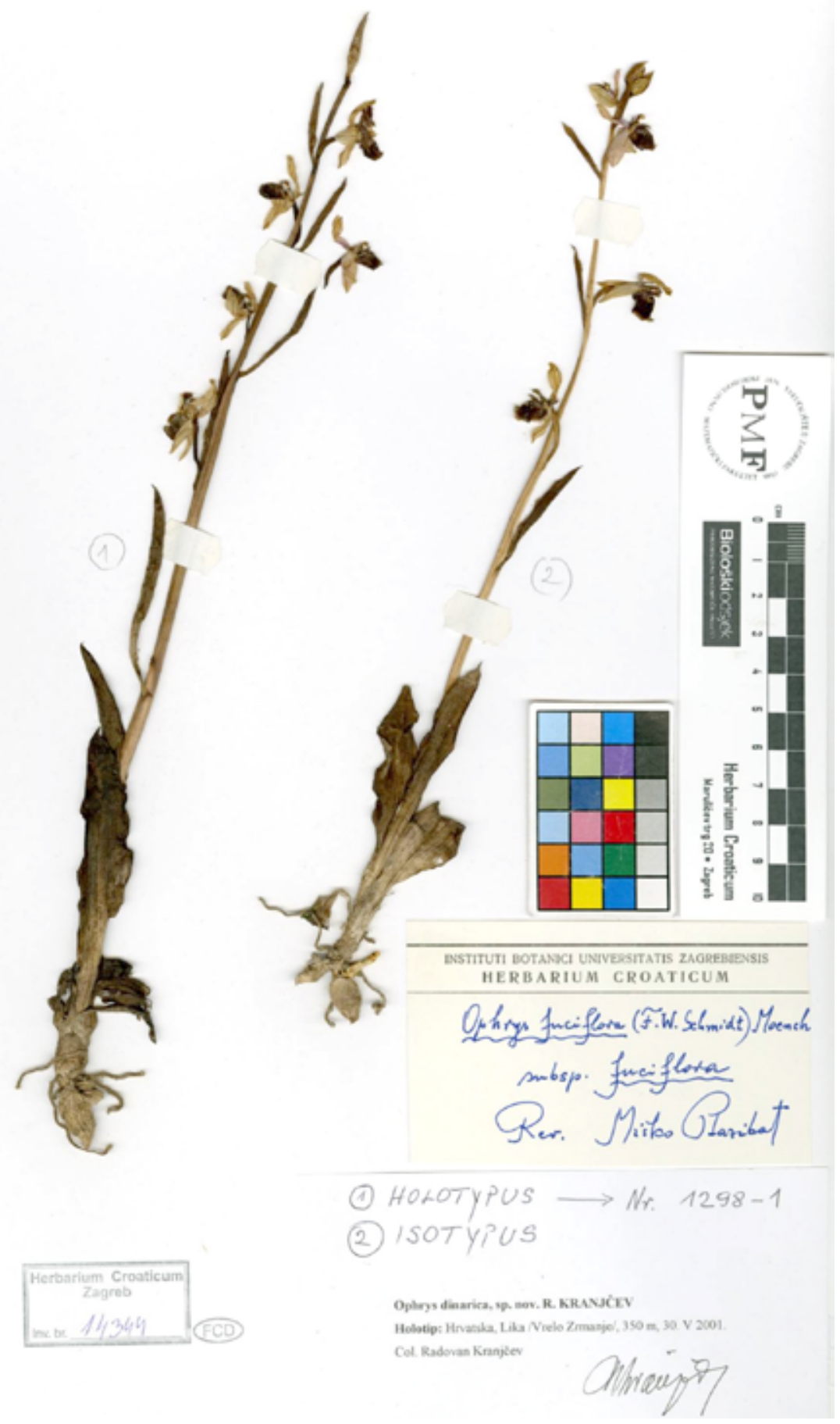

Fig. 2. Holotype and isotype of Ophrys dinarica Kranjčev et P. Delforge (ZA14344) 
The most numerous orchid genera within ZA in terms of number of taxa are Ophrys (18), Orchis (11), Anacamptis (9) and Epipactis (8). As for the number of herbarium sheets, the most numerous genera are Orchis (213), Ophrys (181), Anacamptis (150), Cephalanthera (118), Dactylorhiza (117), Epipactis and Gymnadenia (109 each) (Fig. 3).

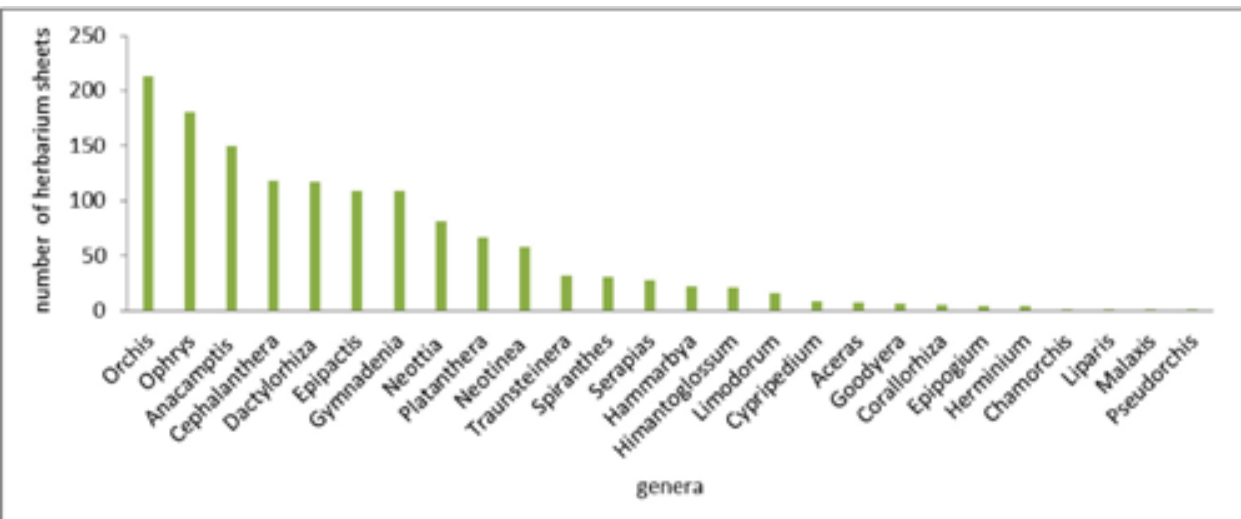

Fig. 3. The most numerous orchid genera in terms of number of herbarium sheets

As for the number of herbarium sheets of particular taxa, the most numerous orchids are Gymnadenia conopsea (78), Platanthera bifolia (59), Anacamptis morio (52), Neotinea tridentata (50), Cephalanthera longifolia (47) and Dactylorhiza maculata (46) (Fig. 4). On the other hand, $40 \%$ of taxa are represented with less than five herbarium sheets, including 19 taxa with only one herbarium sheet.

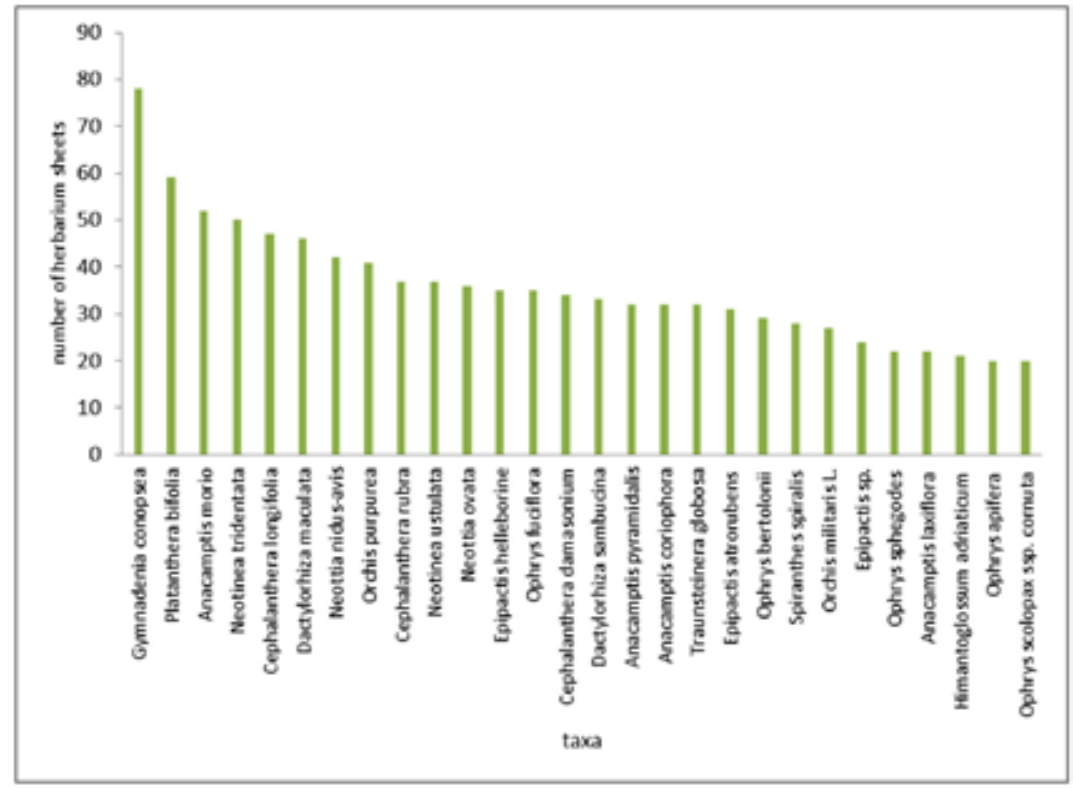

Fig. 4. The most numerous orchid taxa within ZA collection 
As expected, the majority of herbarium sheets (90\%) had been collected in Croatia, while the rest originate mainly from the neighbouring countries Slovenia $(6.7 \%)$, Serbia (1.2 \%), Bosnia \& Herzegovina (0.9\%), Italy (0.9\%), while a single herbarium sheet was collected from both North Macedonia and Montenegro (Fig. 5).

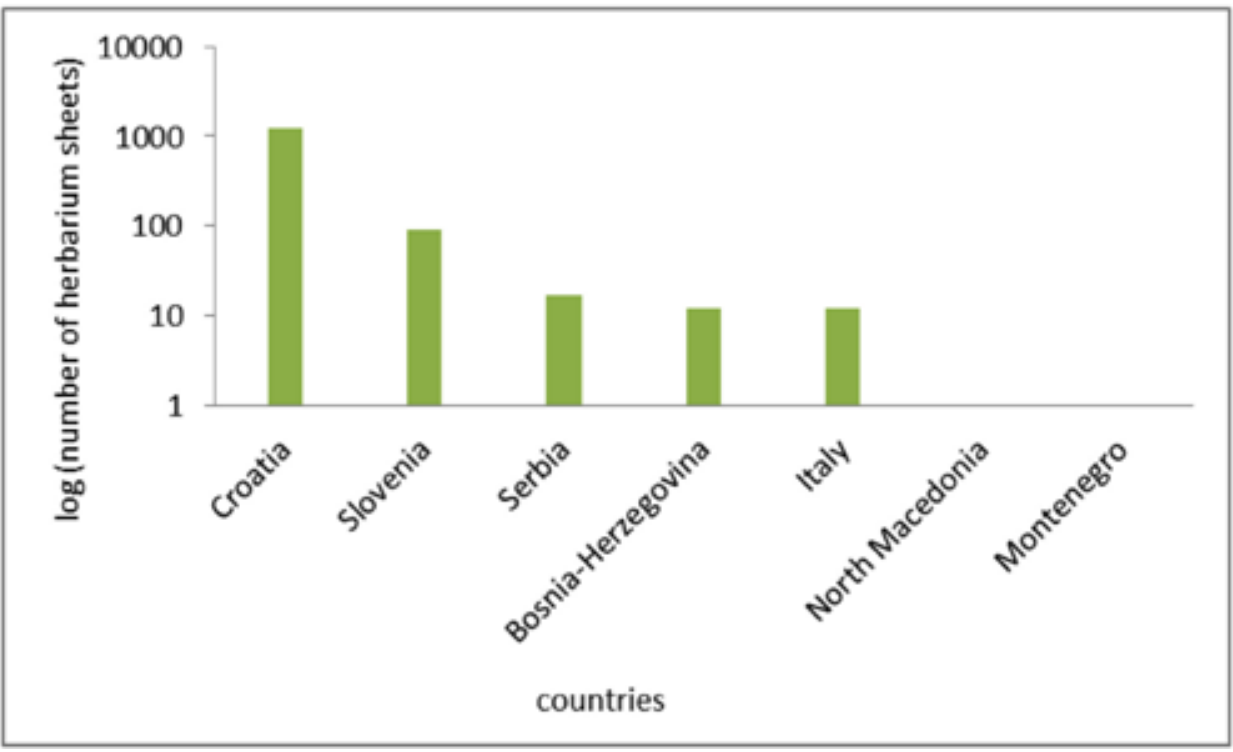

Fig. 5. Geographical origin of orchids stored within ZA collection

Several rare taxa, with no records from Croatia, were collected only in Slovenia, namely Chamorchis alpina, Gymnadenia miniata, Gymnadenia $\times$ heufleri, Hammarbya paludosa, Liparis loeselii, Neotinea $\times$ dietrichiana and Pseudorchis albida. Interestingly, we have found a few sheets with no other proof of their occurrence in Croatia, apart from the herbarium sheets, and these were Malaxis monophyllos from Ivanščica Mt. (Fig. 6), Herminium monorchis from Čabar (Fig. 7) and Ophrys $\times$ muellneri from the island of Lošinj (Fig. 8). Similarly, the finding of the same taxa (Malaxis monophyllos and Herminium monorchi) in Hungarian herbaria validated the unambiguous presence of these two extinct Hungarian species (Molnár et al., 2012b). In addition, herbarium sheets of Ophrys fusca ssp. iricolor, Ophrys tenthredinifera and Epipactis rivularis found in ZA represent a valuable confirmation of these rare species in Croatia.

Regarding the geographical references, $10 \%$ of sheets had no geodata on the herbarium label, or it was not possible to decode the collectors' handwriting nor to find historical toponyms on the available maps. The available records were used to produce a distributional map, shown in Fig. 9. Regarding the time of 
collection, $17.6 \%$ of herbarium sheets lacks temporal information. However, we can aproximate the timeframe for majority of records, due to the known life span of collectors. The oldest sheets are Orchis pallens (ZA6818) and Epipactis atrorubens (ZA42165), dating back to 1833, both collected by Ljudevit Vukotinović in March 1833 in Šestine near Zagreb (kod Šestinah) and on $13^{\text {th }}$ and $26^{\text {th }}$ July on Plešivica and Oštrc in Samoborsko gorje Mts. (na Plišivici i Oštrcu u Gori Samoborskoj), respectively. In comparison, in Hungarian orchids collection $10 \%$ of herbarium sheets lack the exact date of collection, while the oldest sheet dates back to 1804 (Molnár et al., 2012b). Among rare and threatened orchid taxa in the Central Balkans, the oldest specimen, Epipactis palustris, was collected as early as in 1851 (Djordjević et al., 2017). As many as $67 \%$ of orchid herbarium sheets in ZA had been collected in the period from 1870 to 1910, while in the last 100 years, only $21.5 \%$ of sheets were stored in ZA (Fig. 10). Solely 14 sheets were collected and stored in ZA in the $21^{\text {st }}$ century. Strikingly, the average age of the collected sheets is 113 years. Evidently, the majority of the orchid collection has been formed during the end of $19^{\text {th }}$ and the beginning of $20^{\text {th }}$ century, revealing almost complete lack of collection effort during the last century. This is at least partially due to the legal restrictions, since the whole orchid family has been strictly protected over the last 50 years, and the prohibition of collection has been in force. On the other hand, along with rapid development of colour photography, it became easier to identify species using photographs, rather than using dried specimens normally exhibiting severe colour change, therefore the "need" for collection is far less justified in modern times. In Hungary, similar decrease in the number of collected orchids is coincident with the shift from floristics and taxonomy to other fields of botany, pointing that collection has become somewhat "old-fashioned" (Molnár et al., 2012b). On the other hand, the growing importance of legal species protection does not seem to have played a significant role, since there has also been a reduction in collecting other, non-protected taxa (Molnár et al., 2012b).

The main collectors were Ljudevit Rossi with 330 herbarium sheets, Dragutin Hirc with 269 sheets and Ambroz Haračić with 128 sheets (Fig. 11), encompassing $53 \%$ of the collection. As many as 94 collectors participated in total, however 83 $\%$ of all collectors have collected less than ten sheets each. In Hungarian orchid collection, $36 \%$ of the collectors have only one sheet, whereas two-thirds of the collection comes from 10 \% of the collectors (Molnár et al., 2012b). In ZA, only 14 sheets lack the information on collectors, or the collector could not be identified through the handwriting. 

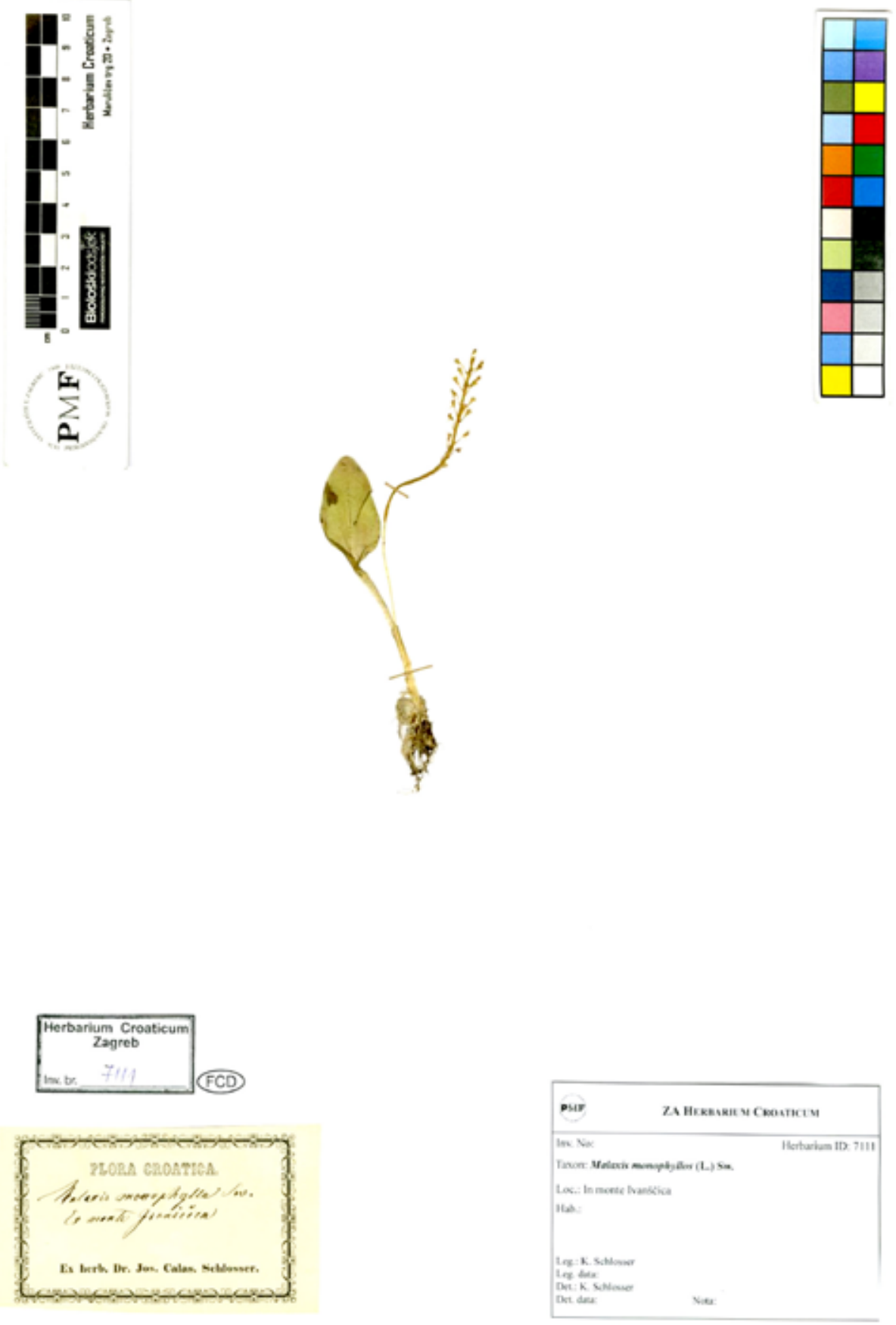

Fig. 6. Specimen of rare Malaxis monophyllos from Ivanščica Mt. (ZA7111) 

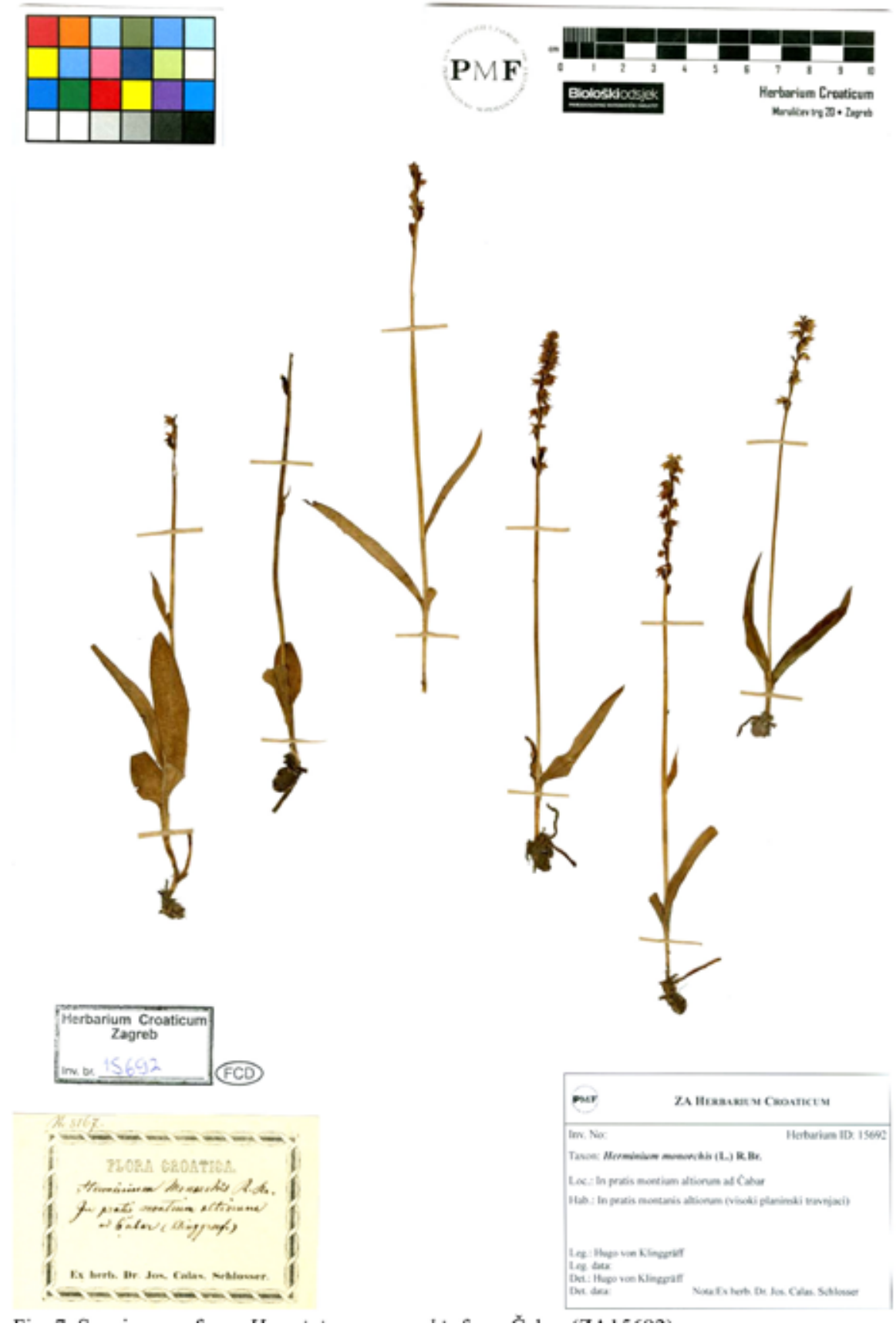

Fig. 7. Specimens of rare Herminium monorchis from Čabar (ZA15692) 

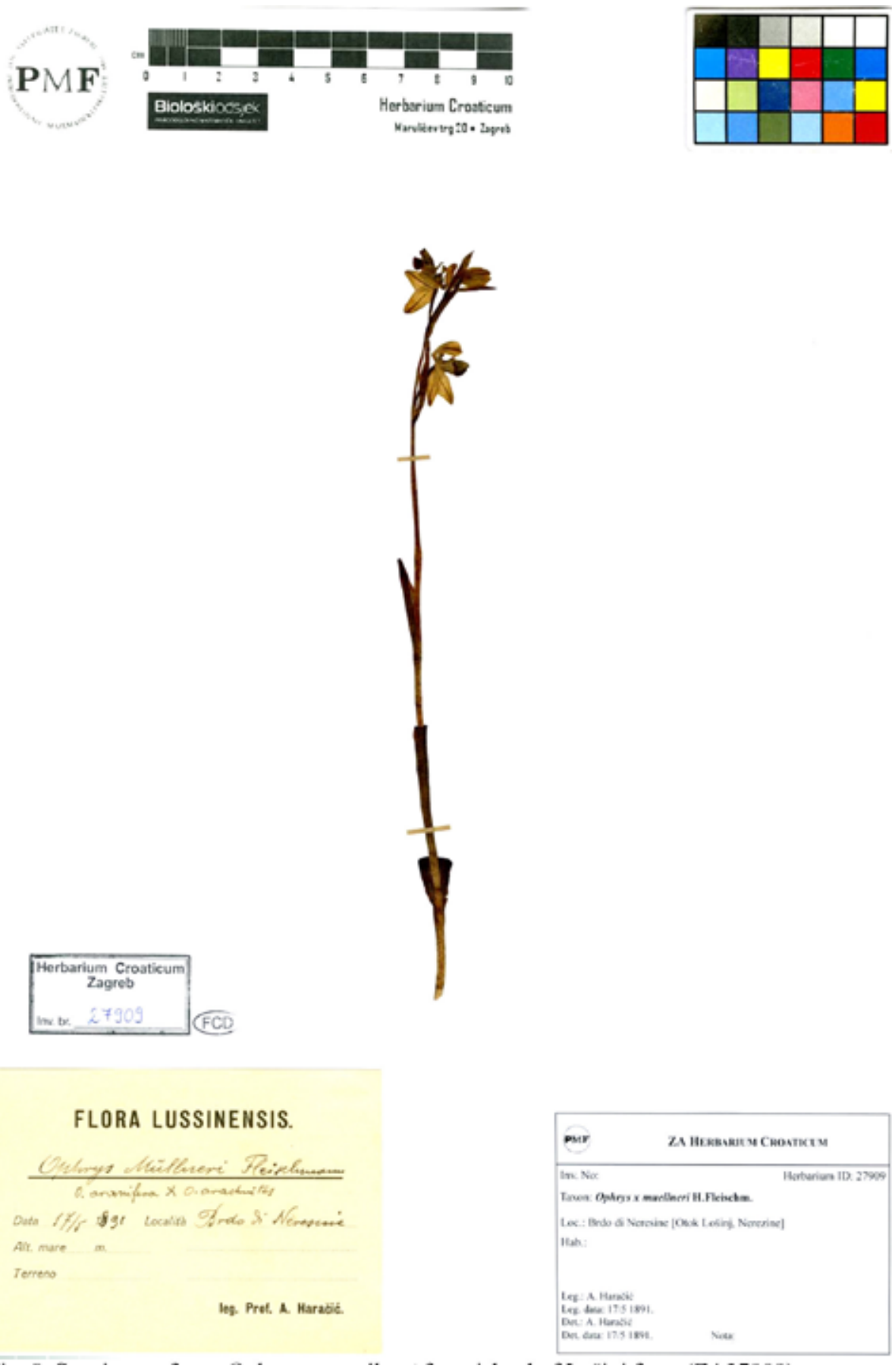

Fig. 8. Specimen of rare Ophrys $\times$ muellneri from island of Lošinj (ZA27909) 


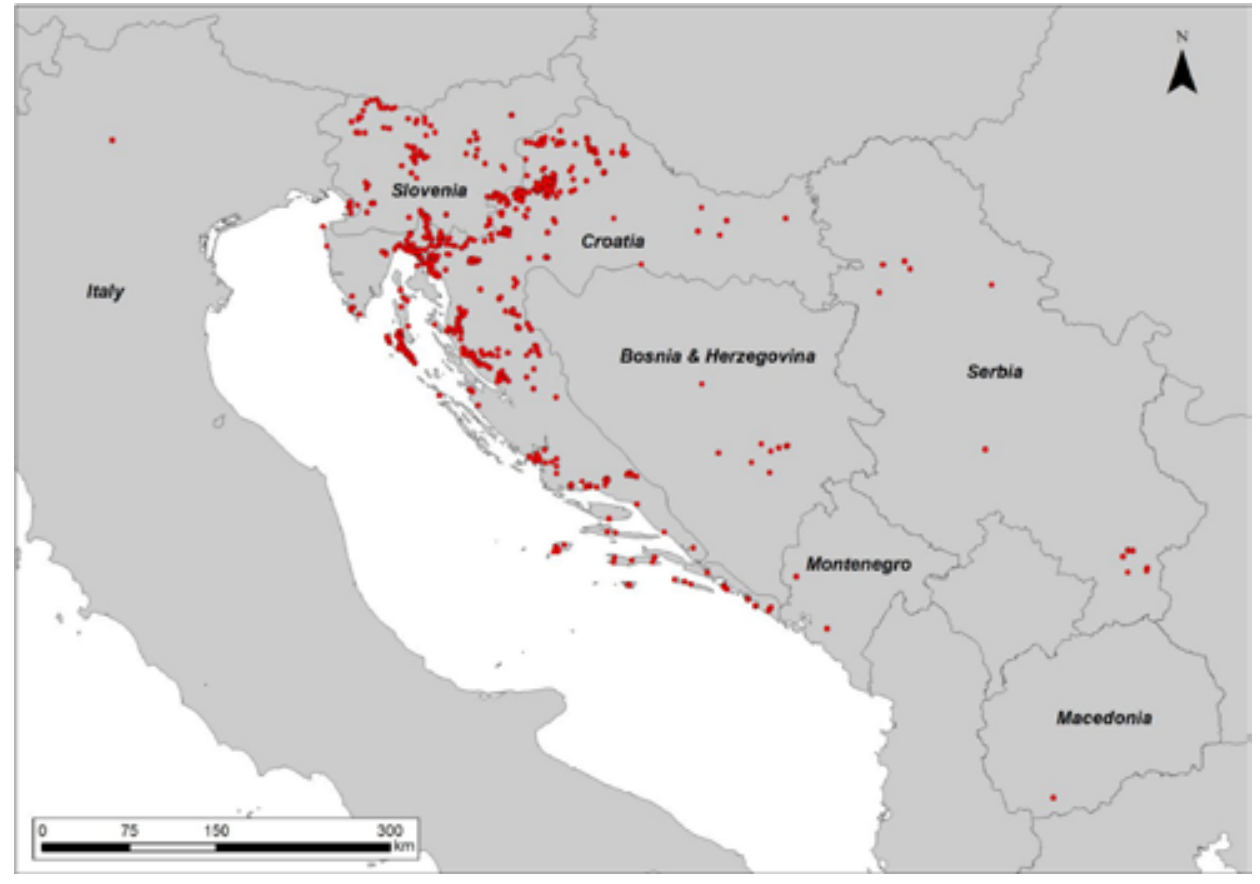

Fig. 9. Distribution map of orchid taxa from ZA collection

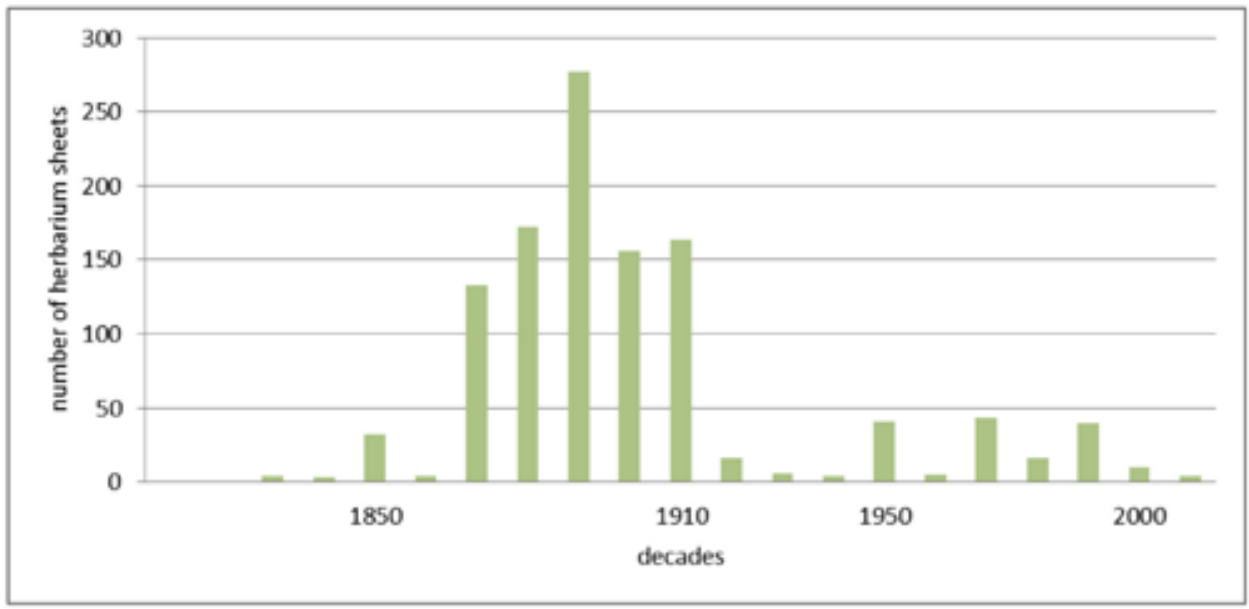

Fig. 10. Temporal distribution of herbarium sheets based on collection period shown in decadal scale 


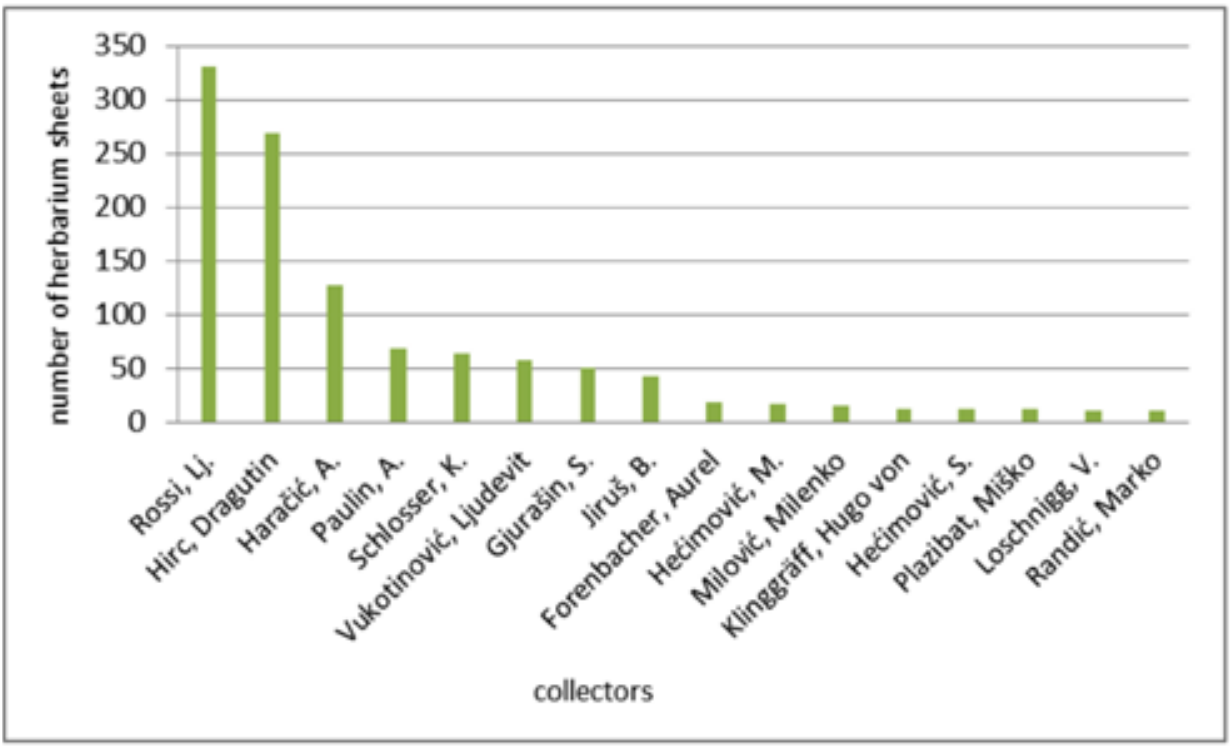

Fig. 11. The most productive orchid collectors in ZA

Finally, based on the experience gained through the entire process, i.e. the specimens' preparation, translocation and restauration, label transcription, georeferencing in GIS environment, scanning, photo processing and uploading to the database, we have managed to estimate the average time of 15 minutes required to fully digitize a single herbarium sheet. It was observed that the label transcription (the decoding of the handwriting) as well as georeferencing (searching for toponyms) represent the main bottlenecks during the digitization process.

\section{ACKNOWLEDGMENTS}

The authors would like to thank students of Faculty of Humanities and Social Sciences for partially participating in the digitization process, through the practical course Digitisation and migration of the documents, and our colleague Anja Rimac for providing the distributional map.

Received February 20, 2018

\section{REFERENCES}

Bateman, R.M., Pridgeon, A.M. \& Chase, M.W., 1997: Phylogenetics of subtribe Orchidinae (Orchidoideae, Orchidaceae) based on nuclear ITS sequences. 2. Infrageneric relationships and reclassification to achieve monophyly of Orchis sensu stricto. Lindleyana 12(3), 113-141.

BorovečKI-Voska, LJ., 2010: Orhideje na Strahinjščici i susjednim područjima. ALFA Zagreb.

BorovečKI-VoskA, LJ., 2016: Serapias × ambigua Rouy ex E.G.Camus (Orchidaceae) u hrvatskoj flori. Glasnik Hrvatskog botaničkog društva 4(2), 29-31.

Britvec, M, Bogdanović, S., Vitasović Kosić, I., Ljubičić, I., Dujmović Purgar, D., Poje, M. \& Pavić, V., V., 2018: Analiza kultiviranih i samoniklih korisnih biljaka u ZAGR Herbariju Agronomskog FAKUlteta. Natura Croatica 27(2), 399-406. 
Broggi, M.F. \& Burri, C., 2006: The orchid flora and distribution of species on the island of Vis (eastern Adriatic, Croatia). Acta Botanica Croatica 65(2), 147-160.

Crvenka, M., 1999: Hrvatske orhideje. Slikovnica izabranih kaćuna. Inmedia, Zagreb.

Delforge, P., 2006: Orchids of Europe, North Africa and the Middle East. Timber Press.

Djordjević, V., Lakušić, D., Jovanović, S. \& Stevanović, V., 2017: Distribution and conservation status of some rare and threatened orchid taxa in the central Balkans and the southern part of the Pannonian Plain. Wulfenia 24, 143-162.

Djordjević, V., Niketić, M. \& Tomović, G., 2018: Liliopsida: Orchidaceae. In: Niketić, M. \& Tomović, G.: Kritička lista vrsta vaskularne flore Srbije 1. Lycopodiopsida, Polypodiopsida, Gnetopsida, Pinopsida i Liliopsida [Katalog taksona]:. Srpska akademija nauka i umetnosti, Beograd, 102-110.

FlanNerY, M.C., 2012: Flatter than a pancake: Why scanning herbarium sheets shouldn't make them disappear. Spontaneous Generations: A journal for the History and Philosophy of Science 6(1), 225-232.

Fleischmann, H., 1904: Zur Orchideen-Flora Lussins. Verhandlungen der Zoologisch-Botanischen Gesellschaft in Wien 54, 471-477.

Göltz, P. \& Reinhard, H., 1986: Orchideen in Jugoslawien. Ein Beitrag zur Kenntnis der Orchideenflora des Balkans. Mitteilungsblättern des Arbeitskreis Heimische Orchideen Baden-Württemberg 18(4), 689-827.

Goodwin, Z. A., Harris, D. J., Filer, D. \& Scotland, R. W., 2015: Widespread mistaken identity in tropical plant collections. Current Biology 25, 1066-1067.

Griebel N., 2009: Die Orchideen Istriens und deren Begleitflora. http://norbertgriebl. jimdo.com/ berichte/, accessed on 1 January 2018.

HAYEK, A., 1913: Zur Kenntnis der Orchideen flora von Dalmatien und Tunis. Östereichische Botanische Zeitschrift 63(12), 494-495.

Hellmayr, C. E., 1939-1941: Notes sur quelques Orchidées de 1’ Adriatique. Candollea 8, 151-172.

Hertel, S. \& Hertel, K., 2003: Die Orchideen der Inseln Cres und Lošinj. Mitteilungsblättern des Arbeitskreis Heimische Orchideen Baden-Württemberg 35(4), 685-721.

HRŠAK, V., 2002: Taxonomic and chorologic revision of the Polypodium vulgare complex in Herbarium Croaticum and the Ivo and Marija Horvat Herbarium. Acta Botanica Croatica 61(1), 45-49.

Hršak, V., Nikolić, T., Plazibat, M., Jelaska, S. D. \& Bukovec, D., 1999: Orchids of Medvednica Natural Park, Croatia. Acta Biologica Slovenica 42, 13-37.

JeričEvić, M., JeričEvić, N. \& Jasprica, N., 2015: Nova svojta kaćunovice (Orchidaceae) u Hrvatskoj. Glasnik Hrvatskog botaničkog društva, 3(3), 34-39.

Kerschbaumsteiner, H., Perko, M. L. \& Stimpfl, G., 2002: Die Orchideenflora Istriens und der Kvarner Inseln Krk, Cres und Lošinj - Ein Vorbericht der Arbeitsgruppe. Mitteilungsblättern des Arbeitskreis Heimische Orchideen Baden-Württemberg 34(1), 115-127.

Kislov, D. E., Bakalin, V. A., Pimenova, E. A., Verkholat, V. P. \& Krestov, P. V., 2017: An electronic management system for a digital herbarium: development and future prospects. Botanica Polonica. A journal of plant science and conservation. 6(2), 59-68.

Kranjčev, R., 2001: Orchids on the Island of Vis (eastern Adriatic - Croatia). Acta Botanica Croatica, 60(1), 69-74.

Kranjčev, R., 2005: Hrvatske orhideje: prilozi za hrvatsku floru: staništa, svojte, hibridi, zaštita. Agencija za komercijalnu djelatnost.

Lang, P. L. M., Willems, F. M., Scheepens, J. F., Burbano, H. A. \& Bossdorf, O., 2019: Using herbaria to study global environmental change. New Phytologist 221(1), 110-122.

Löschl, E., 1971: Orchideen der jugoslawischen Adriaküste. Orchidee 2, 71-73.

Molnár, A.V., Tökölyi, J., Végvári, Z., Sramkó, G., Sulyok \& Barta, Z., 2002b: Pollination mode predicts phenological response to climate change in terrestrial orchids: a case study from central Europe. Journal of Ecology, 100(5), 1141-1152.

Molnár, A.V., Takács, A., Horváth, O., Vojtkó, A.E., Király, G., Sonkoly, J., Sulyok, J. \& Sramkó, G., 2012b: Herbarium Database of Hungarian Orchids I. Methodology, dataset, historical aspects and taxa. Biologia 67(1), 79-86.

Niкоlı́́, T. (ed.), 2019: Flora Croatica Database. On-line (http:// hirc.botanic.hr/fcd) Division of Botany, Faculty of Science, University of Zagreb, accessed on 1 November 2019.

Pavlus, N. (ed.), 2004: Orhideje Nacionalnog parka Plitvička jezera. Javna ustanova “Nacionalni park Plitvička jezera". 
Penn, M.G., Cafferty, S. \& Carine M.A., 2017: Mapping the history of botanical collectors: spatial patterns, diversity, and uniqueness through time. Systematics and Biodiversity 16(1), 1-13.

РеRко, M. L., 1998: Ergänzungen zur Flora von Istrien (Kroatien/Hrvatska): Serapias istriaca M. L. Perko, spec. nov. und Serapias $\times$ pulae M. L. Perko, nothospec. nov. (Orchidaceae). Berichte aus den Arbeitskreisen Heimische Orchideen 15, 13-27.

REŠETNIK, I. \& ŠEGOTA, V., 2018: Virtual herbarium ZA \& ZAHO. On-Line (http://herbariumcroaticum. biol.pmf.hr/) Division of Botany, Faculty of Science, University of Zagreb, accessed on 1 November 2019.

ŠEGOTA, V. \& Alegro, A., 2011: First record of the rare myco-heterotrophic orchid Epipogium aphyllum Swartz on Mt Velebit (Croatia). Natura Croatica 20(2), 437-441.

Šegota, V., BuzjaK, S., Vilović, T., Sedlar, Z., Rešetnikv, I. \& Bogdanović, S., 2017: Curators in action: intricate genus Fritillaria L. (Liliaceae) from ZA, ZAHO, CNHM and ZAGR revised and digitized. Glasnik Hrvatskog botaničkog društva 5(2), 4-14.

Š́gota, V., HršAK, V. \& Alegro, A., 2012: Cephalanthera damasonium (Mill.) Druce in Mediterranean evergreen vegetation. Natura Croatica 21(1), 247-254.

SEREgIN, A. P., 2016: Making the Russian flora visible: fast digitisation of the Moscow University herbarium (MW) in 2015. Taxon 65(1), 203-209.

Smith, V. S. \& Blagoderov, V., 2012: Bringing collections out of the dark. ZooKeys 209, 1-6.

Strgulc KRAJŠEK, S., ŠEgedin T. \& JogAn, N., 2009: Revizija rodova Epilobium i Chamerion u hrvatskim herbarima ZA i ZAHO. Natura Croatica 18(1), 155-167.

Thiers, B., 2018: Index Herbariorum. On-Line (http://sweetgum.nybg.org/ih/) A global directory of public herbaria and associated staff. New York Botanical Garden's Virtual Herbarium, accessed on 1 January, 2019.

VIDović, S., 2001: Pregled osjetljivih, ugroženih i rijetkih biljnih vrsta iz Herbarske zbirke Prirodoslovnog odjela Muzeja Slavonije. Osječki zbornik, 24-25(20), 163-177.

Vöтн, W. \& LöschL, E.,1978: Zur Verbreitung der Orchideen an der östlichen Adria. Linzer Biologische Beiträge 10, 369-130.

VRBEK, M. \& FiedLeR, S., 1998: The distribution, degree of threat to and conservation of the orchids of Žumberak (Croatia). Natura Croatica 7(4), 291-305.

Vuković, N., Brana, S. \& Mitić, B., 2011: Orchid diversity of the cape of Kamenjak (Istria, Croatia). Acta Botanica Croatica 70(1), 23-40.

Vuković, N., Šegota, V., Sedlar, Z., Jelaska, S. D. \& HrŠak, V., 2017: On the orchids of Krka National Park. U: MARGUš, D.: Zbornik radova sa znanstveno-istraživačkog skupa Vizija i izazovi upravljanja zaštićenim područjima prirode $u$ Republici Hrvatskoj: Aktivna zaštita i održivo upravljanje $u$ Nacionalnom parku „Krka“. Javna ustanova „Nacionalni park Krka“. 144-150.

Vuković, N., Tommasoni, A. \& D’Onofrio, T., 2013; The orchid Ophrys speculum Link (Orchidaceae) in Croatia. Acta Botanica Croatica 72(1), 185-191.

WCSP, 2019: World Checklist of Selected Plant Families. Kew: Royal Botanic Gardens. On-Line (http:// apps.kew.org/wcsp/) accessed on 1 December 2019.

Zadravec, M., BorovečKi-Voska, Lj. \& ŠinceK, D., 2013: Ponovni nalaz vrste Orchis simia Lam. i hibridne svojte Orchis $\times$ hybrida Boenn. ex Rchb. (Orchidaceae) na Medvednici. Glasnik Hrvatskog botaničkog društva 1(2): 17-18.

Zadravec, V., Zadravec, M. \& Zadravec, M., 2014: Orchids of Vejalnica and Krč (Medvednica). Glasnik Hrvatskog botaničkog društva 2(1), 4-12.

Zadravec, V., Zadravec, M. \& Zadravec, M., 2015: New finds of Orchis simia Lam. and Orchis $\times$ beyrichii A.Kern. (Orchidaceae) at eastern Medvednica (near Zagreb, Croatia). Glasnik Hrvatskog botaničkog društva 3(3), 29-33.

Zima, D., Đurkić, M. \& TomašEvić, M., 2006: Analiza ugroženosti svojti iz porodice Orchidaceae u Požeškoj kotlini i okolnom gorju. Agronomski glasnik: Glasilo Hrvatskog agronomskog društva 68(2), 99-107.

Ževrnja, N. \& Vladović, D., 2008: Analiza herbara Andrije Andrića. Natura Croatica 17(1), 27-33. 
Appendix 1. Taxa list of orchids in ZA collection. The nomenclature follows BATEMAN et al. (1997) and World Checklist of Kew Gardens (WCSP, 2019). Synonyms in brackets are names used in Flora Croatica database.

Anacamptis

Anacamptis coriophora (L.) R.M.Bateman, Pridgeon \& M.W.Chase

(syn. Orchis coriophora L., incl. Orchis coriophora L. ssp. fragrans (Pollini) K.Richt.)

Anacamptis laxiflora (Lam.) R.M.Bateman, Pridgeon \& M.W.Chase

(syn. Orchis laxiflora Lam.)

Anacamptis laxiflora (Lam.) R.M.Bateman, Pridgeon \& M.W.Chase ssp. laxiflora

(syn. Orchis laxiflora Lam. ssp. laxiflora)

Anacamptis morio (L.) R.M.Bateman, Pridgeon \& M.W.Chase

(syn. Orchis morio L.)

Anacamptis morio subsp. picta (Loisel.) Jacquet \& Scappat.

(syn. Orchis morio L. ssp. picta (Loisel.) K.Richt.)

Anacamptis palustris (Jacq.) R.M.Bateman, Pridgeon \& M.W.Chase subsp. palustris

(syn. Orchis laxiflora Lam. ssp. palustris (Jacq.) Bonnieret Layens)

Anacamptis palustris subsp. elegans (Heuff.) R.M.Bateman, Pridgeon \& M.W.Chase

(syn. Orchis laxiflora Lam. ssp. elegans (Heuff.) Soó)

Anacamptis papilionacea (L.) R.M.Bateman, Pridgeon \& M.W.Chase

(syn. Orchis papilionacea L.)

Anacamptis pyramidalis (L.) Rich.

Cephalanthera

Cephalanthera damasonium (Mill.) Druce

Cephalanthera longifolia (L.) Fritsch

Cephalanthera rubra (L.) Rich.

Chamorchis

Chamorchis alpina (L.) Rich.

Corallorhiza

Corallorhiza trifida Châtel.

Cypripedium

Cypripedium calceolus L.

Dactylorhiza

Dactylorhiza cordigera (Fr.) Soó

Dactylorhiza incarnata (L.) Soó

Dactylorhiza maculata (L.) Soó

Dactylorhiza majalis (Rchb.) P.F.Hunt et Summerh.

Dactylorhiza sambucina (L.) Soó

Dactylorhiza viridis (L.) R.M.Bateman, Pridgeon \& M.W.Chase

(syn. Coeloglossum viride (L.) Hartm.)

Epipactis

Epipactis atrorubens (Hoffm.) Besser

Epipactis helleborine (L.) Crantz

Epipactis microphylla (Ehrh.) Sw.

Epipactis nordeniorum Robatsch

Epipactis palustris (L.) Crantz

Epipactis pontica Taubenheim

(syn. Epipactis helleborine (L.) Crantz ssp. pontica (Taubenh.) H.Sund.)

Epipactis purpurata Sm.

Epipactis rivularis Kranjčev et Čičmir

Epipogium 
Epipogium aphyllum Sw.

Goodyera

Goodyera repens (L.) R.Br.

Gymnadenia

Gymnadenia conopsea (L.) R.Br.

Gymnadenia densiflora A. Dietr.

(syn. Gymnadenia conopsea (L.) R.Br. ssp. densiflora) (Wahlenb.) K.Richt.

Gymnadenia miniata (Crantz) Hayek

(syn. Gymnadenia rubra Wettst.)

Gymnadenia nigra (L.) Rchb.f.

(syn. Nigritella nigra (L.) Rchb.)

Gymnadenia odoratissima (L.) Rich.

Gymnadenia $\times$ heufleri (A.Kern.) Wettst.

Hammarbya

Hammarbya paludosa (L.) Kuntze

Herminium

Herminium monorchis (L.) R.Br.

Himantoglossum

Himantoglossum adriaticum H.Baumann

Limodorum

Limodorum abortioum (L.) Sw.

Liparis

Liparis loeselii (L.) Rich.

Malaxis

Malaxis monophyllos (L.) Sw.

Neotinea

Neotinea lactea (Poir.) R.M.Bateman, Pridgeon \& M.W.Chase

(syn. Orchis lactea Poir.)

Neotinea maculata (Desf.) Stearn

Neotinea tridentata (Scop.) R.M.Bateman, Pridgeon \& M.W.Chase

(= Orchis tridentata Scop.)

Neotinea tridentata (Scop.) R.M.Bateman, Pridgeon \& M.W.Chase ssp. commutata (Tod.)

R.M.Bateman, Pridgeon \& M.W.Chase

(syn. Orchis tridentata Scop. ssp. commutata (Tod.) Nyman)

Neotinea ustulata (L.) R.M.Bateman, Pridgeon \& M.W.Chase

(= Orchis ustulata L.)

Neotinea $\times$ dietrichiana (Bogenh.) H.Kretzschmar, Eccarius \& H.Dietr.

Neottia

Neottia cordata (L.) Rich. (syn. Listera cordata (L.) R.Br.)

Neottia nidus-avis (L.) Rich.

Neottia ovata (L.) Bluff \& Fingerh. (syn. Listera ovata (L.) R.Br.)

Ophrys

Ophrys apifera Huds.

Ophrys bertolonii Moretti

Ophrys bombyliflora Link

Ophrys fuciflora (F.W.Schmidt) Moench

Ophrys fuciflora subsp. fuciflora (syn. Ophrys dinarica Kranjčev et P.Delforge)

Ophrys fusca Link

Ophrys fusca Link ssp. iricolor (Desf.) K.Richt.

Ophrys insectifera L.

Ophrys lutea Cav. 
Ophrys scolopax Cav.

Ophrys scolopax Cav. ssp. cornuta (Steven) E.G.Camus

Ophrys sphegodes Mill.

Ophrys sphegodes subsp. araneola (Rchb.) M.Laínz (= Ophrys sphegodes Mill. ssp. tommasinii (Vis.) Soó)

Ophrys sphegodes Mill. ssp. atrata (Rchb.f.) A.Bolòs

Ophrys sphegodes Mill. ssp. sphegodes

Ophrys tenthredinifera Willd.

Ophrys $\times$ albertiana E.G.Camus

Ophrys $\times$ muellneri H.Fleischm.

Orchis

Orchis anthropophora (L.) All. (= Aceras anthropophorum (L.) W.T.Aiton)

Orchis italica Poir.

Orchis mascula (L.) L.

Orchis mascula (L.) L. subsp. speciosa (Mutel) Hegi (= Orchis mascula (L.) L. ssp. signifera (Vest) Soó)

Orchis militaris L.

Orchis pallens L.

Orchis pauciflora Ten. (= Orchis provincialis Balb. ssp. pauciflora (Ten.) Camus)

Orchis provincialis Balb. Ex Lam. \& DC.

Orchis purpurea Huds.

Orchis quadripunctata Cirillo ex Ten.

Orchis simia Lam.

Platanthera

Platanthera bifolia (L.) Rich.

Platanthera chlorantha (Custer) Rchb.

Pseudorchis

Pseudorchis albida (L.) Á.Löve et D.Löve

Serapias

Serapias cordigera L.

Serapias lingua L.

Serapias parviflora Parl.

Serapias vomeracea (Burm. f.) Briq.

Spiranthes

Spiranthes aestivalis (Poir.) Rich.

Spiranthes spiralis (L.) Chevall.

Traunsteinera

Traunsteinera globosa (L.) Rchb. 
